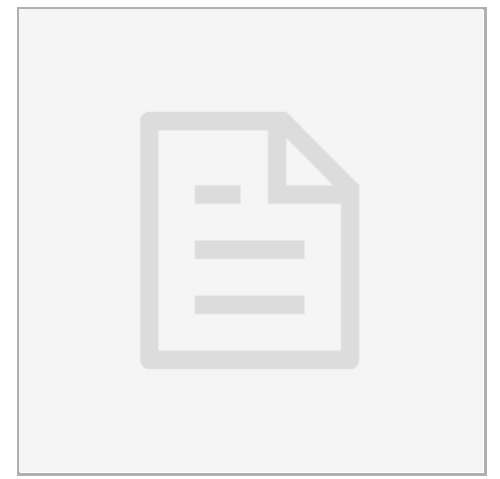

NOV 01, 2019

\section{open $\boldsymbol{\partial}$ Access}

\section{DOI:}

dx.doi.org/10.17504/protocol s.io.y4ffytn

Protocol Citation: Teesha C Luehr 2019. Cell lysis, detergent-free. protocols.io https://dx.doi.org/10.17504/p rotocols.io.y4ffytn

\section{MANUSCRIPT CITATION:}

https://doi.org/10.1074/mcp. M114.047407

License: This is an open access protocol distributed under the terms of the Creative Commons Attribution License, which permits unrestricted use, distribution, and reproduction in any medium, provided the original author and source are credited

Protocol status: Working We use this protocol and it's working

Created: Mar 12, 2019

Last Modified: Nov 01, 2019

PROTOCOL integer ID: 21351

\section{(3) Cell lysis, detergent-free \\ Forked from Cell lysis, detergent-free}

\section{Teesha C Luehr ${ }^{1}$}

\section{${ }^{1}$ University of British Columbia}

\section{Leonard Foster's Lab}

\section{Teesha C Luehr}

University of British Columbia

\section{ABSTRACT}

Detergents are generally not compatible with mass spectrometers, so this is a detergent-free method of cell lysis that is compatible with mass spectrometry. Since this protocol does not have a precipitation step, it saves time and minimizes sample loss as well.

\title{
Growing Cells
}


1 Culture HeLa cells in Dulbecco's modified Eagle's medium (DMEM) containing 10\% FBS, 20mM glutamine, and $1 \%$ PenStrep.

2 Original protocol uses $5 \times 10^{7}$ cells per sample. Use $2 \times 10^{7}$ cells. Use one $15 \mathrm{~cm}$ Petri dish or 2-3 10 $\mathrm{cm}$ dishes. Each $10 \mathrm{~cm}$ dish gives $8.8 \times 10^{6}$ cells.

\section{Preparing Solutions and Materials Needed}

3 Ice Bucket

4

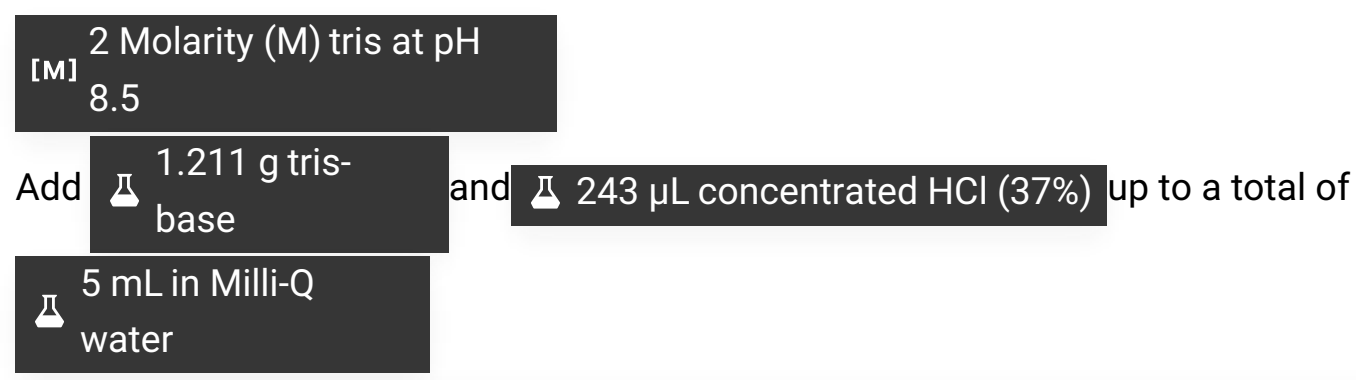

Note

Calculations done with https://www.cytographica.com/lab/HHTris.html.

Note

Tris-base is in NCE 438 chemical room on the top right doubles shelf

Note

A stock conical tube of ${ }^{[\mathrm{M}]} \begin{aligned} & 2 \text { Molarity }(\mathrm{M}) \\ & \text { tris }\end{aligned}$ is stored on the bench. 


\section{5}

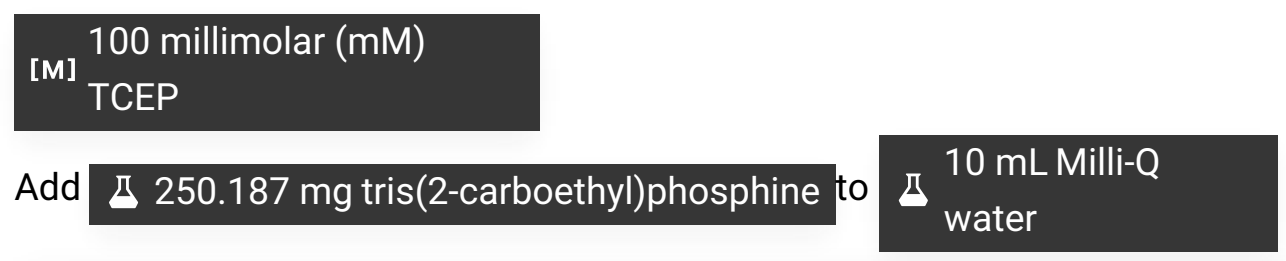

Note

TCEP is located in NCE $436-20 \mathrm{C}$ freezer door (currently the top shelf)

Note

\ $405 \mu \mathrm{L}$ aliquots of ${ }_{\text {[M] }}^{100 \text { millimolar }(\mathrm{mM})} \begin{aligned} & \text { TCEP } \\ & \text { have been made and are stored in }\end{aligned}$ Teesha's $8_{\text {box }}^{-20{ }^{\circ} \mathrm{C} \text { storage }}$

6

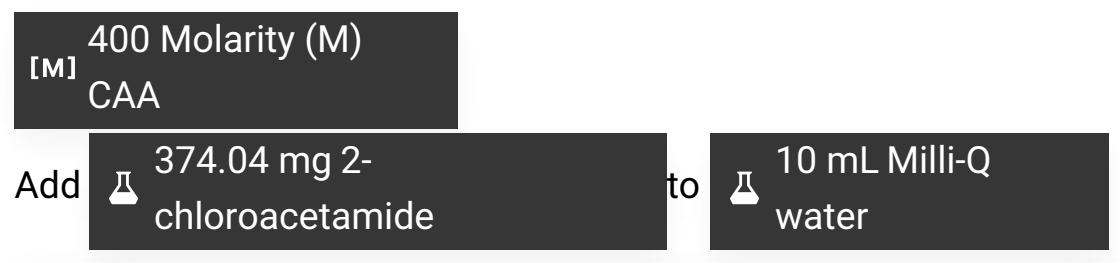

Note

CAA is located in NCE 438 chemical room on the "C" shelf

Note

\ $405 \mu \mathrm{L}$ aliquots of ${ }_{\text {[м] }}^{400}$ millimolar $(\mathrm{mM})$ have been made and are stored in

Teesha's $\AA^{\circ} \begin{aligned} & -20{ }^{\circ} \mathrm{C} \text { storage } \\ & \text { box }\end{aligned}$ 


\begin{tabular}{|c|c|}
\hline $\begin{array}{l}50 \text { millimolar (mM) } \\
\text { NH4HCO3 }\end{array}$ & \\
\hline dd $\Delta \begin{array}{l}197.4 \mathrm{mg} \text { ammonium } \\
\text { bicarbonate }\end{array}$ & \ـ $\begin{array}{l}50 \mathrm{~mL} \text { Milli-Q } \\
\text { water }\end{array}$ \\
\hline
\end{tabular}

Note

Upscale or downscale volume needed. Up to $15 \mathrm{~mL}$ will be used for each replicate.

8

$85^{\circ} \mathrm{C}$ heating

\section{Pellet Cells}

9

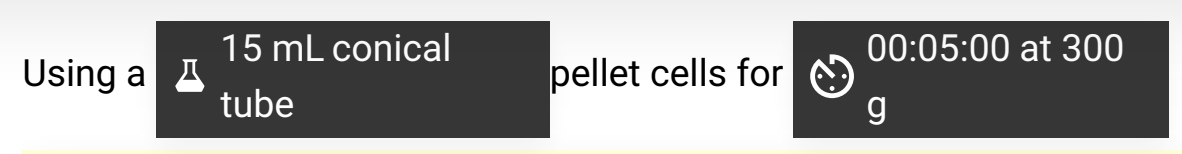

Note

Pellet in a tube a minimum size of $\triangle 15 \mathrm{~mL}$ as this tube will be used through till the end of digestion.

10 Wash cells with $\Delta_{\mathrm{PBS}}^{10 \mathrm{~mL} \text { cold }}$

11 Pellet cells for $\bigcup_{\mathrm{g}}^{00: 05: 00}$ at 300

12 Carefully discard supernatant 
13 Store cell pellet on ice

Note

If not performing cell lysis immediately, the pellet can be stored at

$8^{\circ}-80^{\circ} \mathrm{C}$ until further

use.

\section{Cell Lysis}

14

Resuspend the cell pellet(s) in $\Delta_{\text {water }}^{1.5 \mathrm{~mL} \text { ice cold Milli-Q }}$

Note

Perform the lysis and digestion in the $\Omega_{\text {tube }}^{15 \mathrm{~mL} \text { conical }}$. The lysis volumes,

sonification, and digestion require the larger tube volume.

15

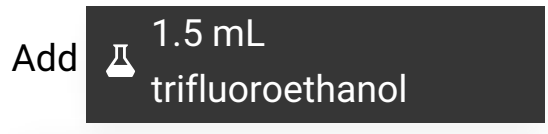

Safety information

This step should be done in the fume hood.

Note

1:1 water-TFE acts as a hypotonic aqueous buffer to lyse cells, eliminating the need for detergent. TFE helps protein solubility and denaturation; it readily evaporates, so removing it is easy. 
Note

TFE is located in the NCE 435 flammable cabinet.

Note

TFE evaporates fast, so work quickly.

16

$$
\text { Cool for } 00: 10: 00 \text { on }
$$

17

$$
\text { Mix the sample for } 0 \begin{aligned}
& 00: 01: 00 \text { with a } \\
& \text { vortex }
\end{aligned}
$$

18 Sonicate the sample for 00:02:00 with the Branson Digital Sonifier 250 at 30\% amplitude in pulse mode (pulse ON for $0.2 \mathrm{~s}$ and pulse OFF for $0.8 \mathrm{~s}$ ) with the tapered micro tip probe.

\section{Note}

The Branson Sonifier is the cell distrupter of choice, however, the bench top water bath sonicator can be used for 10 minutes.

\section{Reduction \& Alkylation}

19 Add $\triangle 200 \mu \mathrm{L} 2 \mathrm{M}$ tris for a final concentration of [M] 100 millimolar $(\mathrm{mM})$

20 Mix the sample for $0 \begin{aligned} & 00: 00: 05 \text { with a } \\ & \text { vortex }\end{aligned}$ 
21

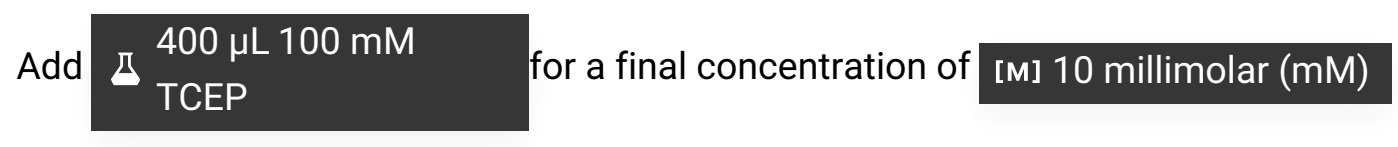

22 Mix the sample for $\overbrace{\text { vortex }}^{00: 00: 05 \text { with a }}$

23 Add \ $\begin{aligned} & 400 \mu \mathrm{L} \\ & \text { CAA }\end{aligned} 400 \mathrm{mM}$ for a final concentration of [M] 40 millimolar (mM)

24 Mix the sample for 00 vo:00:05 with a

25 Incubate in the heating block for $00: 10: 00$ at $88^{\circ} 95^{\circ} \mathrm{C}$

\section{LysC Digestion}

26

Dilute the sample to a total of

\section{ـ $15 \mathrm{~mL} 50 \mathrm{mM}$ \\ $\mathrm{NaHCO} 3$}

Note

This is performed to dilute the TFE.

27 Measure the protein concentration with a NanoDrop (using SCOPES A205 Protein) 
28 Calculate the total amount of protein that is desired to carry forward with the experiment. Keeping in mind that the final peptide concentration will be approximately $10-50 \%$ of the protein concentration at this step. Transfer this volume to a new tube. If small enough, transfer to a

\section{$2 \mathrm{~mL}$ lo-bind}

tube

29

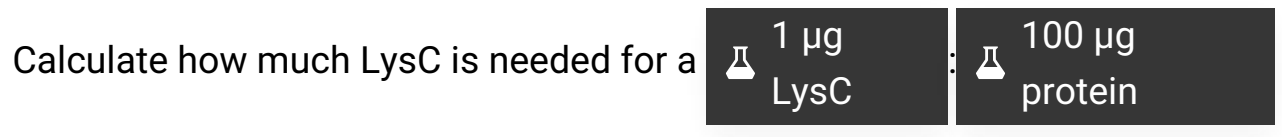

30 Add the calculated amount of LysC to the sample

Note

Lys $\mathrm{C}$ is in the $8^{\circ} \begin{aligned} & -80^{\circ} \mathrm{C} \\ & \text { freezer }\end{aligned}$

31

Incubate for $02: 00: 00$ at $8^{\circ} \begin{aligned} & 37^{\circ} \mathrm{C} \text { in the } \\ & \text { incubator }\end{aligned}$

\section{Trypsin Digestion}

32

Calculate how much trypsin is needed for a

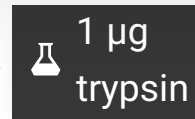

$\pi \begin{gathered}100 \mu g \\ \text { protein }\end{gathered}$

33 Add the calculated amount of trypsin to the sample

Note

Trypsin is in NCE 435 -20 freezer in the door, bottom shelf 
34 Incubate for a minimum of $16: 00: 00$ at $8^{\circ} \begin{aligned} & 37^{\circ} \mathrm{C} \text { in the digestion } \\ & \text { incubator }\end{aligned}$

\section{Second Trypsin Digestion}

35

$$
\text { Calculate how much trypsin is needed for a } \Delta \begin{gathered}
1 \mu \mathrm{g} \\
\text { trypsin }
\end{gathered}
$$

Note

A second trypsin digestion is optional. User digression is advised.

36 Add the trypsin to the sample

37 Incubate for $05: 00: 00$ at $88_{\text {incubator }}^{37^{\circ} \mathrm{C} \text { in the digestion }}$

\section{STAGE Tip}

38 Proceed to the STAGE tip protocol 